\title{
RELECTURAS Y CREACIÓN DESDE LA SUBVERSIÓN: SUSANA Y LOS VIEJOS, DE MARTA SANZ
}

\author{
RE-READING AND CREATION FROM SUBVERSION. \\ SUSANA Y LOS VIEJOS, DE MARTA SANZ \\ Blas SÁNCHEZ DUEÑAS \\ Universidad de Córdoba \\ blasanadu@gmail.com
}

Resumen: Este artículo analiza la visión crítica de la sociedad actual y la revelación de zonas oscuras de la tradición sagrada occidental a través de la relectura y recreación narrativa de la historia de Susana y los viejos realizada por Marta Sanz.

Abstract: This article analyzes the critical vision of the current society and the revelation of dark zones in sacred western tradition through the rereading and narrative recreation of the story of Susana and the old men done Marta Sanz.

Palabras clave: Recreación. Biblia. Transgresión. Crítica Social. Marta Sanz. Susana y los viejos.

Key Words: Recreation. Bible. Transgression. Social criticism. Marta Sanz. Susana y los viejos. 


\section{PRELIMINARES}

La tradición cultural occidental se ha nutrido históricamente de los libros de la Biblia como inagotable manantial de inspiración artística. En el capítulo decimotercero del Libro de Daniel, escrito hacia el 165 a. de C. e incluido en el Antiguo Testamento entre los de Ezequiel y Oseas, se recoge la historia de Susana y los viejos que, como otros muchos escritos del Libro Sagrado, se ha convertido en estímulo para la creación literaria, escultórica o pictórica.

Si se recuerda brevemente, este relato narra la historia de la bella y temerosa sierva del Señor, Susana, esposa de Joaquín, quien al medio día acostumbraba a pasear por el hermoso jardín de su casa. Dos honorables jueces ancianos que solían impartir justicia en casa de Joaquín al ver la hermosura de Susana comienzan a desearla y a perder el juicio por ella hasta que ambos, al descubrir su incontrolada pasión, deciden sorprenderla a solas.

Ocultos hasta encontrar la idónea oportunidad para satisfacer sus turbadores deseos, aprovechan la ausencia del marido y la soledad de Susana para amenazarla e instarla a ilícitas proposiciones, bajo amenaza de que si no accediera a su petición la acusarían de adulterio con un joven. Al rechazar la deshonesta proposición de los ancianos, éstos cumplen su amenaza y la acusan, celebrándose un juicio sumario en el que la asamblea toma parte a favor del tradicional respeto y dignidad de los ancianos frente a los testimonios de una mujer, por lo que la condenan a la lapidación. Sin embargo, ante la fe y rectitud demostrada por Susana y la súplica a la misericordia divina, Dios se apiada de ésta y, por intersección de Daniel, se descubre la inmoral imputación de los ancianos, gracias a las contradicciones advertidas en los testimonios de aquellos al decir uno que el adulterio se había producido bajo una encina y declarar el otro que los habían sorprendido bajo una acacia. Desvelada la calumnia de los ancianos, el pueblo los castiga con la misma pena que se le había impuesto a Susana, quedando restaurada la honra de la casta y devota protagonista.

Los ingredientes de esta mítica narración, mujer hermosa y fiel, acusación de adulterio, morbo y carnalidad del desnudo en el baño, los deseos incontrolados de dos ancianos, en principio y según la tradición, modelos de honorabilidad, moralidad, rectitud y sabiduría, los falsos testimonios, fe inquebrantable, sentencia a muerte y redención por intersección divina, etc., así como las posibilidades creativas que la historia posibilitaba, pronto despertó el interés de escritores y pintores que, a lo largo de los siglos, plasmaron en sus creaciones la morbosa escénica bíblica. 
Desde Tintoretto a Rubens pasando por Alessandro Allori, Guercino, Ricci, Veronese o Rembrandt, Goya, Dalí o Artemisia Gentileschi o autores como Frischlin, Rebhun o Salus, el arte pictórico y la creación literaria han plasmado la escena bíblica desde diferentes ángulos o perfiles expresivos.

Una nueva versión y una renovadora perspectiva del antiguo episodio testamentario ofrece en el alba del siglo XXI Marta Sanz en su novela Susana y los viejos (2006) con la que quedó finalista del primero Nadal de 2006, otorgado en la convocatoria de ese año a Eduardo Lago por Llámame Brooklyn, y también del premio Salambó - al mejor libro de narrativa publicado en dicho año-que recayó en El abrecartas, de Vicente Molina Foix.

Con esta obra, según palabras de la propia autora, lo que Sanz procura es «dar la vuelta al pasaje bíblico del Libro de Daniel, para desvelar algunas zonas oscuras de nuestra doble moral. Concretamente, las zonas que tienen que ver con nuestra vivencia de la decrepitud, la vejez, la enfermedad y, finalmente, la muerte. Susana y los viejos se adentra en esos territorios con la idea de que el sentimiento trágico de la vida nunca debería arrebatarnos la alegría de vivir ni las ganas de transformar el mundo» (García, 2006). Y, a la vez, pretende hablar «del amor y de la muerte, de la confrontación sexual y de clase, de lo que pasa dentro de las habitaciones y de los espacios públicos, de los ritos y de las ceremonias compartidas, de qué pasa cuando alguien no ama como se espera que debe hacerlo» (García, 2006), colocando al lector en una posición incómoda: en la de los viejos del cuadro de Susana. «En la posición vouyerística de esos viejos que al mismo tiempo que desean y juzgan, son deseados y juzgados. Como los propios lectores» (García, 2006). A Marta Sanz el pasaje bíblico le fascinaba «por su contenido moral, pero también porque, con sus distintas versiones pictóricas, se pone de manifiesto que es una metáfora de la mirada, de la lectura y de las implicaciones que conlleva leer desde un lugar u otro. Además tanto la Susana de los cuadros, como la de la novela, son personajes que ofrecen, al contemplador, al lector, una desnudez llena de pureza. En el ojo a menudo es donde está la viga, no en el objeto de la contemplación» (García, 2006).

Así, pues, la autora, con esta obra, pretende forjar un nuevo lienzo literario sobre el ancestral relato bíblico, fijando su atención tanto en la protagonista femenina, Susana, como sobre sus dos antagonistas los viejos, hilvanando una mirada a la tradición literaria más canonizada como la representada por un texto sagrado del libro de libros en los comienzos del siglo XXI. 


\section{MARTA SANZ: RUPTURAS Y EXTRAÑAMIENTOS}

La relación con la literatura de esta escritora madrileña, nacida en 1967, ha sido siempre cercana y más que estrecha, ya que es Doctora en Literatura Contemporánea por la Universidad Complutense de Madrid y profesora en la Universidad Antonio de Nebrija. De sus datos biográficos ${ }^{1}$ hasta la fecha de publicación de la novela objeto de estudio, lo que se más se repite es que fue redactora jefe de la revista cultural $N i$ hablar y que ha colaborado con distintas publicaciones periódicas como ABC, Escuela de Noche o Viento Sur. Junto a ello, caben mencionarse sus colaboraciones en el diario El País, también en el periódico El público y con el Instituto Cervantes, así como en el blog de literatura La tormenta en un vaso, que se completan con sus textos para la revista digital Literaturas.com y para la revista literaria-cultural Mercurio.

Su producción narrativa la abrió en 1995 con la novela El frío (Madrid: Debate, 1995) a la que siguieron Lenguas muertas (Madrid: Debate, 1997) y Los mejores tiempos (Madrid: Debate, 2001), por la que recibió el Premio Ojo Crítico de Narrativa de Radio Nacional de España en 2001 y en la que se interroga acerca del porqué los hijos de los progres de los sesenta se han hecho conservadores.

Animales domésticos (Madrid: Destino, 2003) supuso un salto en su creación por el número de reseñas y el impacto causado por la novela. En ella se destilan muchas de las claves, obsesiones, preocupaciones, caracteres y núcleos compositivos de la literatura de Marta Sanz. A Susana y los viejos le ha seguido, hasta la fecha, Lección de anatomía (Barcelona: RBA, 2008), novela narrada en primera persona por una voz femenina que evoca su vida desde la infancia hasta los cuarenta años, realizando una vivisección personal por medio de la indagación psicológica y sexual, para plantear el aprendizaje y el proceso de construcción de la propia identidad; y Black, black, black (Barcelona: Anagrama, 2010), novela negra con componentes propios del sistema narrativo de Marta Sanz, donde no falta la crítica, la violencia, los conflictos personales y la penetración psicológica en los personajes y donde el lector se ve asaltado por una intricada trama que lo irá sacudiendo hasta el desenlace final.

Por otro lado, ha ensayado modalidades de relato breve encontrándose textos suyos en volúmenes colectivos como Páginas amarillas y Daños co-

${ }^{1}$ Una completa bibliografía sobre la autora puede verse en la página web dedicada a ella en la Cátedra Miguel Delibes: http://www.catedramdelibes.com/archivos/001186.html. 
laterales, Hazañas antibélicas ambos publicados en la editorial Lengua de trapo. Asimismo, sus relatos aparecen en otras publicaciones de carácter antológico como Escritores contra la tortura (1997) y Escritores contra el racismo (1998) -editados en Madrid por Talasa-, La vida por delante. Voces desde y hacia Palestina (Madrid: Fundamentos, 2005), Todo un placer (Córdoba: Berenice, 2005) y Leyendas de Bécquer (Madrid: 451 Editores, 2007). En esta faceta, la obra de Marta Sanz ha sido reconocida no sólo con su aparición en las obras corales anotadas, sino también al haber sido distinguida con el premio Vargas Llosa NH de Relatos de 2006 con su cuento Regalos.

Para completar esta somera silueta de su obra no hay que olvidar la coordinación de dos volúmenes colectivos: uno de cuentos titulado Rojo, amarillo, morado. Cuentos republicanos (Barcelona: Martínez Roca, 2006) y una antología poética que lleva por título Metalingüísticos y sentimentales. Antología de la poesía española (1966-2000) Cincuenta poetas hacia el nuevo siglo (Madrid: Biblioteca Nueva, 2007).

Escritora con una arraigada personalidad y conocedora de los entresijos del mundo literario tanto desde el punto de vista de la creación como desde el de la recreación ya sea crítica, docente o investigadora, la literatura de Marta Sanz parte de unos cañamazos muy concretos, asumidos, conscientes y defendidos tanto en sus planteamientos discursivos como en sus praxis novelescas: «Iluminar facetas de la realidad desapercibidas, abordándolas intrépidamente. Desvelar esa realidad y conectar las experiencias del lector con las del escritor» (Sanz, 2003a). Es decir, sus creaciones se originan y parten desde el presente, de la realidad inconfesada o desatendida que nos rodea para ofrecerla con toda su crudeza, su paroxismo, sus obsesiones y su calado, porque, para ella, la literatura tiene que hacer visible las cosas ya visibles pero no vistas o presentadas en su rigor. Debe ser una lupa de la cotidianeidad que, expuesta a través del amplificador cristal de la lente literaria, muestre las realidades que nos rodean, aunque no las queramos ver o aunque tratemos de desviar nuestras miradas hacia otro lado.

En medio de la postmoderna fragmentación y variedad de la narrativa española intersecular y de un mercado literario y cultural fiscalizado desde los grandes grupos editoriales, Marta Sanz en un sabroso artículo, titulado Ver, oír y no callar (2007), disecciona el mundo del libro de ficción en el siglo XXI, apuntando algunas de las claves del best-sellerismo y de la literatura como producto destinado al entretenimiento y al consumismo fácil, causas, entre otras, del estado y consideración de la narrativa en la actualidad. Frente al conformismo, el seguidismo, la ortodoxia y la docilidad tanto de lecto- 
res como de autores, proclama «desde la literatura, una actitud en las antípodas de la resignación: ver, oír y no callar. Tomar conciencia de las trampas en las que todos los días caemos y, aún así, intentar no callarse ni debajo del agua. Resistirse a una felicidad falsa, ñoña, estúpida, complacida y complaciente. Resistirse a bestsellerizarse y procurar no morir. Romper, desde los libros, las lunas de los escaparates del mercado editorial y de una ideología que nos corta las alas con el rostro amable de quien nos las estuviera dando. Procurar que los peces grandes no se coman a los pequeños peces editoriales y peces escritores» (2003a).

Esta actitud combativa, digna de ser ponderada como merece, no obstante, no deja de ser una demagógica declaración de intenciones, toda vez que, en las circunstancias actuales, donde falta el silencio de los que escuchan y sólo se tiene el ruido de los que compran (Bértolo, 1996: 44), persuadidos y cautivados por la seducción de un espacio mercantil, los escritores claudican ante los gustos de un público acrítico y maleable - consumidor y dócil degustador de unos mismos clichés compositivos-, acaudillados ambos - escritores y lectores - desde los centros mercantiles y la escaparatista concepción de la literatura como producto de consumo contra el que es difícil una davidiana insurrección.

Sin embargo, contra las formas canónicas y lo hegemónico, Marta Sanz desde la atalaya del inconformismo y la autocrítica al arte narrativo, desde su irrupción en el panorama literario nacional, ha tratado de hurgar en las acomodaticias tendencias narrativas y de aguijar con sus mundos de ficción las continuidades, falta de referentes de compromiso y/o elusiones de los discursos novelescos en el período que encabalga el siglo XX y el XXI.

La escritora madrileña se separa de su predecesores inmediatos, los novelistas de la llamada «Nueva Narrativa» — Vázquez Montalbán, Eduardo Mendoza, Rosa Montero, Jesús Ferrero- con la intención de que la literatura tenga repercusión, entendida ésta como efecto inductor que no deje indiferente al lector, de forma que la obra le impacte de tal manera que lo despierte del sopor, de lo acomodaticio, de la ceguera y del ostracismo y que por medio de sus personajes y de su descarnado lenguaje el lector repare en esa realidad circundante e inmediata que le rodea y que día a día pasa desapercibida sin querer verla o sin detenerse a contemplarla.

Adopta, pues, una actitud de riesgo frente al mundo y lo establecido, similar a la de otros narradores denominados como neorrealistas o aquellos otros de la denominada cofradía del cuero (Martín, 1997: 13-15) como José Ángel Mañas, Ray Loriga, Daniel Múgica, Pedro Maestre, Benjamín Prado 
o Lucía Etxebarría, a través de una literatura que deja huella y que huye de las banalidades y vacuidades, así como de los estereotipos, estilos o corrientes dominantes. Su escritura parte de la rebeldía y del compromiso ${ }^{2}$ con la finalidad de azotar las embobadas conciencias de los seres humanos de hoy mediante una práctica narrativa cruda (hiper)enfocada, diáfana y sin cloroformos que impacte y aguijonee, que comunique y estimule, que haga pensar y recapacitar, que formule y denuncie.

Muestra de ello es que sobre una de las tendencias narrativas más notables de los años ochenta y noventa, la denominada metaliteratura o endoliteratura, una tendencia espiral que centraba sus tramas, argumentos o leitmotivs en los propios artificios o nudos literarios, en la exploración de la escritura o en la novela como fuente de creación para la propia narrativa, se alzó la autora de Susana y los viejos por su desinterés por lo cotidiano, por no lanzarse contra los problemas reales y los entornos sociales preocupantes y sólo recrearse en estructuras y dobleces de la propia literatura sin atender la nueva colmena en la que se estaba convirtiendo España, donde se hacinan inmigrantes y muchos viejos se mueren de soledad en el mismo medio de la ciudad.

Con estos matices, Marta Sanz parte de los postulados de una renovación narrativa que entronca con los axiomas de una auténtica novela social con libertad formal y estilística, fuera de cualquier dogmatismo artístico. Su narrativa es rupturista, de «incorrectamente política» ha llegado a ser caracterizada. Se libera de tendencias, dogmas, ataduras o encorsetamientos. Renueva tradiciones heredadas removiendo conciencias y disparando hacia las zonas más sensibles o más perversas del ser humano con la finalidad de desvelar sus conductas hirientes o sus falsedades.

Su formación cultural y su pasión por la literatura y el arte favorecen que sea una notable conocedora de la tradición literaria o de las tendencias artísticas. En sus obras, cuadros, piezas musicales, películas, libros, escritores, actores y actrices, cuentos... irrumpen por entre las páginas de sus textos, generando una amplia suerte de intertexualidades desde las que se mira a la cultura pasada para proyectarla hacia las realidades de hoy. En este sentido, Marta Sanz reescribe obras, transgrede cánones, imagina otros mundos y esboza otros paisajes derivados de los originales poniendo en comunicación el arte del pasado con la vida ciudadana del siglo XXI. Si no hace mucho ha ensayado una variación de la becqueriana leyenda de Maese Pérez, el organis-

\footnotetext{
${ }^{2}$ Es interesante la presentación de la autora realizada por López Cabrales (2000: 85-98).
} 
ta en el libro coral Leyendas de Bécquer (Silva, 2007), sobre Animales domésticos ha declarado que su referente se encuentra en la novela Miau, de Pérez Galdós, de la que retoma la galdosiana galería de personajes para, libándola, reflejar el microcosmos de una familia actual y retratar la degradación de la inconformista clase media española, presente a través de unos personajes que no se aceptan, que no asumen su situación, que distraen sus insatisfacciones, pensando que son otra cosa y que coinciden en la búsqueda de excusas a su estupidez cotidiana (Sanz, 2003b).

Si muchas son las influencias subvertidas y emanaciones de la tradición alteradas, presentes en Susana y los viejos, en 2008 volvió a tratar de quebrantar lo circundante con su novela Lección de anatomía, ya que, como ha revelado «convencionalmente, cuando uno escribe una novela autobiográfica parece que tiene que ser muy anciano». Sin embargo, ella, con esta obra, quiere reivindicar un espacio para detenernos, pensar y tomar decisiones (Sanz, 2008), porque, según Sanz, nos estamos dejando llevar por la vorágine diaria. Es por ello por lo que la autora se detiene y realiza un ejercicio de autoconciencia en la que la figura protagonista, máscara-trasunto de la propia escritora, se adueña de sí misma y se evade para sumergirse hacia su interior y su pasado y emerger entre enmascarada y desnuda ante el lector (Becerra, 2008).

Lugar común en su práctica discursiva es la mezcolanza entre ficción y realidad. Si en Lección de anatomía las nebulosas fronteras entre vida real e imaginación, entre autobiografía e invención se confunden, lo que provoca que el lector tenga que ir sorteando interrogantes y estableciendo todo tipo de cautelas sobre lo contado, en sus obras, los lectores se sumergirán en unas historias cargadas de realidad — quizás hiperbolizada- que pretenden exponer fragmentos y vivencias representativas de la sociedad española contemporánea. De hecho la idea de Animales domésticos, según ella misma ha revelado, surgió de una experiencia vivida con un grupo de mujeres que la invitaron a dar una charla sobre la novela de adulterio. Al acabar su intervención, una mujer levantó la mano y me dijo que le había gustado mucho la conferencia, pero que ella tenía un problema: había dejado de leer porque se había dado cuenta de que cuanto más leía, más estúpidos e insuficientes le parecían los miembros de su familia... hasta el punto de transformarse para ella en una pandillita de «animales domésticos» (Díaz, 2008).

Como narradora contracorriente ha tratado de prestigiar la novela realista mediante el rescate de las luces y de las sombras de la realidad para presentarlas y proyectarlas con todos sus perfiles y en una extensa gama de ma- 
tices - por hirientes que puedan resultar- a través de sus ficciones, porque para ella: «la ficción y la realidad son inseparables, igual que el fondo y la forma o la ética y la estética, y de hecho lo que los escritores hacemos es observar lo que nos rodea para maquinar ficciones, inaugurar un punto de vista que no es el de los medios de comunicación de masas y, en la medida de nuestras modestas posibilidades, intervenir en lo real» (Díaz, 2008).

La galería de personajes de Marta Sanz es amplia y diversa. Con todo, se destaca la especial atención que fija en «los viejos, en las familias de una clase media venida a menos, en pugna con los valores de sus mayores. Sus personajes son seres desterritorializados sin haberse exilado de su país. Son hijos conservadores de padres hippies, muchachas tontas en busca de un bebé in vitro y de regreso a la moral de matrimonio y de la domesticidad. Son ingenieros desocupados con problemas de ira y esposas hartas de sus maridos, pero que no los dejan porque no sabrían qué hacer con su libertad» (SantosFebres, 2007).

En líneas generales, su narrativa ofrece una ácida imagen del individuo en la sociedad actual. En ella se enfocan los traumas que azotan a los seres humanos en el alba del siglo XXI, así como las falacias, amoralidades, incomprensiones e incomunicación de la sociedad inmediata. Detalles y excesos se armonizan en medio de una prosa rica en indagaciones psicológicas, miradas siniestras, sórdidas y angustiantes y retratos que desnudan las vidas miserables, turbadoras e insatisfechas de sus protagonistas. Lo cotidiano se describe con crudeza, pero sin renunciar a la ironía, para dibujar un convincente documento colectivo que atisba el fondo de soledad del mundo contemporáneo. Todos estos componentes han influido para que su prosa se haya relacionado con las técnicas e ingredientes definitorios del llamado «realismo sucio». Contra esta caracterización, la autora apostilla su propia percepción o catalogación de su narrativa en los siguientes términos: «yo creo que hago realismo de terror o terror realista, en el sentido de que, si como decía Freud, el terror consiste en hacer extrañas las cosas cotidianas, nuestro mundo está plagado de elementos de extrañamiento, de violencias y de injusticias que convierten la realidad en un lugar a menudo inhabitable. Yo apuesto por ver el horror en primer plano, por desvelarlo, para poderlo combatir» (García, 2006).

Desde el riesgo y la crudeza, la novelística de Sanz plasma las visiones cotidianas que percibe en una pintura global agria y revulsiva, cuyo telar medular gira en torno al microcosmos de la familia, pequeño universo donde se reflejan, con personajes de carne y hueso, las relaciones humanas más di- 
rectas. La autora se vale de los pequeños lugares nucleares, las familias, como vértices de su novelística por ser éstas trasuntos donde se encuentran enquistados los grandes problemas sociales y culturales. Desde aquí, mediante componentes como los que ella misma aduce («extrañamiento, violencias e injusticias») sombrea los tintes de una realidad focalizada desde la perspectiva de la mezquindad, la inhabitabilidad y el horror que invade las sociedades presentes y a sus pobladores. Es decir, como en la pintura negra de Goya, la de Gutiérrez Solana o la de Rembrant, se ofrece, en primer plano y ante la incrédula vista del lector, las angustias y pavores que asolan la vida ciudadana para que, mediante el acto de aprehensión lectora, se puedan percibir para luego combatir las infamias de nuestra sociedad. Marta Sanz adopta una postura de escritora comprometida con proyección ética y moral y con un paisanaje de profunda preocupación social, tratando de buscar los tonos problemáticos y mustios que las acomodaticias clases medias apartan de su vista para no convulsionar sus propias vilezas.

Sus obras se recargan de actos, observaciones, reflexiones, impresiones, indagaciones, acontecimientos dispares y saltos en la línea discursiva temporal y argumental que enriquecen la visión general con el objetivo de zumbar las conciencias y, a la vez, de azotar las acomodaticias y complacientes lecturas de unos receptores poco reflexivos y dóciles ante el mercado editorial con la intención de apartarse de lo dado y de estimular creaciones que combatan el aburguesamiento literario ${ }^{3}$. Como planteaba Ramón Pedregal en una reseña a Lección de anatomía, aplicable al resto de su obra, cuando se bucea en la prosa de Sanz se necesita leer, «no se puede dejar de leer, no hay por dónde abandonar la línea continua de palabras. Y las circunstancias de todo tipo cambian y se deja de ser lo que se era y venga otra cosa y relaciones que

\footnotetext{
${ }^{3}$ Es interesante comparar el punto de partida de Marta Sanz en relación con los cánones, tipologías y características de la novela coetánea para comprobar el camino y la concienciación que separa uno de otra. Así si se consideran los rasgos dominantes de la narrativa actual, en las sintéticas palabras de M. ${ }^{\text {a }}$. Isabel de Castro García (2002: 169): «[...] la vindicación de la narratividad, de la historia, de la acción y de la intriga, la superación del compromiso, el desplazamiento del foco del relato de lo colectivo a lo individual, la incorporación de la ironía y la amenidad y, en general, el propósito de aproximar la novela al público han sido otras tantas constantes sobre las que ésta se ha venido sustentando. Se trata, pues, de una novela ligera y de escasa o ambigua proyección ética o moral salvo excepciones, bien recibida por lectores poco reflexivos y dóciles al dirigismo editorial y a los reclamos publicitarios. Lector que no busca sólidos argumentos ni densas historias o personajes de relieve; un tono menor cotidiano planea sobre lo que se narra, a menudo personal e íntimo, rara vez insólito o extraordinario, de ahí que el término light se haya acreditado como apelativo de esta clase de novela, aunque no siempre sea adecuado a la que despreciativamente se aplica; porque a veces la futilidad es más aparente que real, digna la factura del relato y no desdeñable el propósito», se puede percibir, por lo expresado en el cuerpo del texto, cómo Marta Sanz asume una literatura combativa y provocadora frente a lo liviano, convencional y acomodaticio del panorama prosístico reinante».
} 
brotan y progresan y se desvirtúan con otras irrupciones que abrasan y hacen ceniza lo último y definitivo que la dejan ver más horizonte y dudas y vuelcos que enseñan a tener calma» (Pedregal, 2008).

\section{SUSANA Y LOS VIEJOS, VISIONES SUBVERSIVAS DE LA TRADICIÓN}

Publicada en 2006 y finalista del premio Nadal, Susana y los viejos se estructura en seis partes, cada una de ellas encabezadas con un enunciado: «El cuerpo y el cuerpo», «Savasaná», «Los cuidados paliativos», «La imposible empresa de prever quién va a morir primero», «Retablo de los soles y las lunas» y «La tristeza». De muy desigual extensión, los capítulos uno, tres y cinco ocupan casi el noventa por ciento del libro frente al resto, cuya aportación al conjunto es parca. A su vez, cada una de las seis secciones se construye sobre la base de pequeños fragmentos igualmente desiguales en su longitud, separados por un espacio interlineado algo amplio. Esta construcción en secuencias cortas da agilidad al relato y conecta la obra con técnicas fragmentarias características de los discursos de la postmodernidad (Lyon, 1994). Además, estas formas se comunican con las técnicas narrativas actuales donde la ruptura de la estructura lineal sintagmática se destaca como una de las respuestas del arte a la crisis y el relativismo de las ideologías vigentes (Jameson, 1991), por lo que fondo y forma, contenido y estructura, se arquitraban como procedimientos entrelazados propios de la sociedad actual donde se desenvuelven las historias de los protagonistas sanzianos.

Ante las estructuras cambiantes, relativas y dúctiles de nuestro tiempo, las formas narrativas como la novela Susana y los viejos tratan de captar y reproducir esas inestabilidades y discontinuidades alejándose, de las obras de arte tradicionales cuales pudieran ser esos referentes pictóricos de las representaciones de los cuadros sobre Susana y los viejos. En esta novela, la comunicación narrativa se descompone en escenas hiladas por las problemáticas historias vitales de la familia protagonista del relato que se convertirá en el nudo argumental del libro ${ }^{4}$.

\footnotetext{
${ }^{4}$ «Debemos reparar en que el fragmento es la única respuesta acorde con la disolución de la experiencia estable en la modernidad, es la asunción de la crisis de la epistema clásica que organizaba las similitudes y las semejanzas en un cuadro ordenado. La modernidad es una crisis y un laberinto de lenguajes. El fragmento no ofrece la seguridad del discurso clásico ni la forma afilada y compacta del aforismo, pero sí da cuenta de nuestra experiencia de la precariedad» (Jiménez, 1994: 26).
} 
Sin embargo, los planos narrativos se superponen e intercalan dando lugar a discontinuidades temporales y perspectivas diversas que, además de confundir y complicar la comprensión de los acontecimientos y de las redes relacionales del texto, así como de sus protagonistas, generan la desorientación del lector, quien se ve obligado a realizar un esfuerzo para poder ir encajando los distintos planos temporales y relaciones biográficas del texto.

La narración, situada desde un presente desde el que se controla todo, tiene un ritmo dinámico que produce impresión de vivacidad a la que también contribuye un estilo directo cargado de humor y de sarcasmo. Sin embargo, por un lado, la disgregación es evidente en el plano temporal. El fluir del discurso se aparta de una tradicional secuenciación diacrónica. Santos Sanz (2006) puntualizaba que el argumento de la novela se distribuía en el relato con una marcha zigzagueante «que impide saber muy bien cuál es su motivo central y en ausencia de una idea directriz, se encuentra una acumulación de anécdotas dispersas». El hilo narrativo se destruye y recompone mediante flash-back y flash-foward por medio de los que el lector viaja a la infancia de los protagonistas o a episodios pretéritos de sus vidas o, por el contrario, mediante insinuaciones, haces relacionales e historias indirectas se describe lo que puede o podría ser el desenlace de las existencias de los protagonistas que habitan esta novela. Estos seccionamientos del tiempo provocan que las historias vitales de los personajes vengan siendo conocidas de una manera fragmentaria, disgregándose y recomponiéndose mediante retazos de ayer, revelaciones de hoy, indicios varios y posibilidades futuras que poco a poco van trazando y componiendo la urdimbre sintagmática del relato, así como su nudo vertebral centrado en la narración de la vida e identidad de los actantes narrativos que lo componen. Por ello, la trama de la novela es confusa y las relaciones de las experiencias y vidas de los personajes se fragmentan. Para el conjunto de seres escindidos que protagonizan esta novela, la memoria y sus recuerdos se cargan de ramificaciones que confluyen en variables caprichosas, rememoraciones pretéritas o aspiraciones futuras que el discurso literario va reproduciendo al albur del reflejo o recuerdo eléctrico que sobreviene en la conciencia al hilo de alguna cuestión que obsesione al personaje o a la escena que haga recapitular a la figura literaria en un momento dado.

La madeja de los hilos de la existencia que une a los protagonistas de $\mathrm{Su}$ sana y los viejos se va ofreciendo mediante imágenes, secuencias inconexas o fragmentos intercalados que se van entrelazando, dando lugar a un collage que el lector debe ir recomponiendo para restablecer las líneas sintagmáticas del significante e ir acomodando las fragmentarias alteraciones en la continuidad de las vidas, historias, tiempos y relaciones de los protagonistas. De 
esta manera al lector se le capacita para que participe en la narración, tratando de interrogarse sobre la trama y sobre el final de cada uno de sus personajes, alejándolo así de la tradicional pasividad y obligándolo a intervenir activamente en el proceso de creación de la obra, entrando, pues, en directo diálogo con otras obras postmodernas que se oponen al sistema analítico-referencial de la tradición artística (Navajas, 1987: 14-15).

La novela se conforma como una obra coral vertebrada en torno a tres generaciones de hombres y mujeres de una misma familia: Felipe Amaro y su esposa Micaela; Felipe Amaro (hijo) y su ex-esposa (Lorena) y Maximiliano Amaro, hijo de Felipe y Lorena y Pola, a quienes se unen para completar este microcosmos familiar las figuras de Susana Renan, médica geriatra cuidadora del nonagenario Felipe y segunda esposa de Felipe hijo, y Clara Martínez, empleada del hogar de los Amaro y, en segundo término muy subsidiario, Antonio, el nuevo amante de Lorena.

La narración aparece administrada desde la omnisciencia autorial de un narrador que gobierna el relato y va desgranando y conduciendo secuencias o escenas en principio aparentemente desconectadas o fragmentarias con objeto de ir dándole sentido al conjunto de planos impresionistas que se van intercalando en la historia. Este narrador, situado en el mismo plano temporal del presente de los protagonistas, conoce todos los entresijos de sus relaciones personales, domina lo que piensan de sí mismos y de los demás y es quien va moviendo los hilos de las vidas y las historias de sus personajes hasta ofrecer la totalidad del cuadro narrativo de Susana y los viejos.

Técnicamente, los desdoblamientos y personalidades convulsas de los personajes de la novela de Sanz se construyen mediante el uso de la tercera persona de carácter heterodiegético con utilización recurrente del estilo indirecto libre, acompañado en ocasiones por el discurso directo, si bien, aquél es el más empleado.

Sin embargo, la omnisciente tercera persona narradora no es la única voz que se escucha en la novela, sino que aparece una heterofonía de voces narrativas diversas que se suceden y que provocan cierto desconcierto en el lector, el mismo que invade a los personajes del relato y el mismo que palpita en la sociedad actual.

La narración omnisciente en tercera persona se ve interrumpida por la voz interna de los protagonistas, quienes en primera persona se convierten en narradores de sus vidas mediante un deslizamiento hacia la indagación psicológica personal, desde donde aflorarán sus estados de ánimo, sus pesadi- 
llas, sus obsesiones o sus reflexiones y, con todo ello, su alienación y angustia vital en especial en los capítulos más breves del libro cuyas focalizaciones dirigen y protagonizan Lorena en «Savasaná»; Pola en «La imposible impresa de prever quién va a morir primero»; y Felipe Amaro padre en «La tristeza».

Así pues, en ciertas partes de la obra el punto de vista y las perspectivas narratorias se desplazan desde el narrador a los propios personajes lo que provoca que haya desplazamientos desde la tercera a la primera persona, desde la omnisciencia a la enunciación privada.

En la novela contemporánea la intimidad y los problemas de identidad han pasado a un primer plano por lo que también se ha producido un deslizamiento desde la tercera a la primera persona pronominal. Se ha hablado en esta mudanza de novela de concienciación, bildungsroman, relatos en los que se produce un cuestionamiento interior del individuo (Ciplijauskaité, 1994: 34). Los personajes pretenden saber quiénes son, cómo han llegado a la situación actual. Por ello las evocaciones hacia el pasado y el proceso de forja de la identidad de los protagonistas en sus contextos sociales y familiares pasa a primer plano. Desde la conciencia del presente se reevalúa el pasado buscando explicaciones y tratando de comprender quién se es ahora o el porqué de la situación actual.

Ante identidades escindidas y los problemas de soledad y alienación que atormentan a los seres humanos presentes, los protagonistas novelescos de Sanz pretenden conocer todos los extremos de la realidad que los rodea, descubrir su lugar en el mundo, explicarse los porqués de sus turbaciones y el origen o elucidaciones de su degradación y angustias actuales.

Las verdades absolutas no existen. La realidad no es algo unívoco. Se han perdido las guías ideológicas y se han quebrado los referentes óptico-epistemológicos. Las colectividades y proyectos sociales han dejado paso al individualismo y a la intimidad. Los enfoques conjuntos o las omnisciencias ha sido sustituidos por las ópticas parciales, las miradas individuales, el relativismo y las preocupaciones personales y privadas donde el sujeto aparece como un ser aislado y vacío atormentado por sus dudas e inestabilidad, inseguro de todo, impotente ante el desbordamiento de lo (des)conocido y lanzado en solitario a un precipicio abismal donde se encuentra solo con su ser, sus dudas, sus temores, su incomprensión y su tragedia personal sin saber cómo ni por qué ha llegado a ella.

Ante tales problemáticas de la postmodernidad, los personajes de Susana y los viejos son seres que se saben dueños de una vida miserable cargada de 
sinsabores, rencores, infamias y debilidades. Estas crudas circunstancias vitales y esta galería de personajes conflictivos en permanente conflicto consigo mismos y con los demás serán reveladas a través de la voz del narrador o a través de las propias figuras narrativas de Sanz, quienes penetrarán en su propio interior para desnudarse ante el lector. Así, algunas de las voces narrativas de los protagonistas se sumarán a la del narrador para poblar la obra de varios puntos de vista, interesados en desvelar la alienación, tormentos o desconciertos que caracterizan a los personajes del relato ${ }^{5}$.

Interesa la realidad que envuelve a estos seres, su intimidad. El relato se caracteriza por el proceso de (auto)conocimiento de los protagonistas y de trascendencia de su propias vidas. De ahí que lo importante sea el existencialismo, la introspección, los procesos de (auto)conocimiento, de reflexión y de indagación personal que dominan en la novela ya por boca del narrador ya por las palabras de sus protagonistas. Son sintomáticos los monólogos interiores y las introspecciones hacia las conciencias y furtivos juicios o sentimientos de las figuras de ficción con objeto de plasmar sus estados de ánimo y los recónditos pensamientos que oprimen la psique de los protagonistas.

Así pues, el estudio de la psicología de los personajes, de sus emociones y motivaciones pasa a un primer plano, manteniendo, no obstante, cierto misterio en todo lo referente a Susana cuya vida y existencia es tan misteriosa como atractiva, tan seductora como mítica, tan irreal como espiritual. Por medio de estas indagaciones hacia el interior de los personajes se reflexiona a lo largo de la novela sobre las crisis de identidad y alienación que asolan a los seres humanos de hoy. Son continuas las meditaciones sobre su ser y su estar en la sociedad, así como sobre cómo se ven ellos mismos, cómo perciben su fuero interno y su contexto existencial y su desesperada y deshumanizada situación en las esferas social, afectiva, comunicativa y personal.

Este relato aparece anclado temporalmente en el presente y, aunque parte de la realidad sincrónica de la España del siglo XXI a través de la historia de la familia Amaro, su referente argumental procede de la amplia tradición literaria e iconográfica del episodio de Susana y los viejos. Sin embargo, tanto el tiempo de la narración en presente y una realidad actual sin tiempos determinados hacen que el lector se sumerja en la ficción y que sea un espec-

5 «En relación con la novela española contemporánea, algunos críticos han llamado la atención sobre esta indagación psicológica que se detecta en numerosos textos del momento. Esta introspección muestra a unos personajes que se distancian de lo problemática social para concentrarse en sus propios mecanismos mentales. Sin embargo, y a pesar de los esfuerzos que esto conlleva, el resultado son seres aún confusos e informes que nunca logran autodefinirse completamente» (Ruz, 1999). 
tador privilegiado de una situación de hoy con tintes algo extremos, ya que todos los personajes son seres marcados por las excentricidades y turbaciones, cosa que roza la inverosimilitud si bien se consigue impactar en el lector y hacerlo recapacitar sobre las realidades y doble moral de una clase mediaalta española marcada en esta novela por el fracaso y la decepción.

En una de las reseñas elaborada sobre la obra, Inés Matute (2006) señalaba que «Marta Sanz da la vuelta al conocido pasaje bíblico de Susana y los viejos consiguiendo que Susana pase de observada a observadora, una metáfora de los tiempos en que vivimos». En la misma línea, la autora advertía al respecto que «a Susana la ponen en una situación indecorosa y tiene que intervenir Daniel para salvarla. Me interesaba por todas las representaciones y porque me permite reflexionar sobre el significado de la mirada. Yo reinterpreto la escena para poner de manifiesto la doble moral del mundo en que vivimos» (Gallego, 2006).

La novela comienza in media res. En las primeras palabras del relato el lector advierte la subversión de la secuencia artística clásica, así como la transgresión de la historia heredada de la tradición:

Clara alberga ciertas dudas respecto a la conveniencia de hablar o de callarse. Hace unos días, tuvo quizás una visión. Durante la visita domiciliaria de la geriatra, Clara abrió la puerta y encontró a la doctora Susana Renán, con el torso desnudo, sobre el cuerpo lampiño del abuelo. Clara había abierto la puerta despacito para comprobar si la doctora necesitaba algo y pudo ver, durante algunos segundos, cómo la doctora, a horcajadas sobre el paciente, sin poner encima de él todo su peso, recorría con sus tetas pequeñas la piel del pecho del anciano, como si quisiera conservarlo vivo, dándole calor. [...]

El movimiento, nunca brusco, acabó cuando la doctora, de abajo arriba, alcanzó la boca del abuelo y le dio un beso pelágico, escarbando con su lengua el hueco de la boca del abuelo, quien con ojos inexpresivos se quedó mirando a Clara. [...]

La doctora, abstraída, insistía en la profundidad de su beso, como si pretendiera dejar impoluta la dentadura, la garganta, los bronquios del paciente. La doctora tenía algo de caníbal, aunque fuera ella quien se iba metiendo por la boca agrandada del viejo, para limpiarlo como las rémoras a los tiburones o los parásitos del cuerno afrodisíaco del rinoceronte. [...]. La doctora le mostraba su espalda ancha y el surco de su columna vertebral, los agujeritos que se forma en la parte alta de las nalgas, las plantas blancas de los pies, la curva de los hombros. El abuelo, a lo largo del beso, dejó de mirar a Clara y, sin cerrar los párpados, concentró sus retinas en la bombilla del techo, hasta que la masa del ojo se reblandeció. [...] 
Ahora Clara, después de haber desechado la absurda idea de que su imaginación le juega malas pasadas, no sabe si Susana Renán es una criatura angelical o un monstruo. Ha repasado la escena y, completamente segura de sí misma, se ha dado cuenta, eso sí, con otras palabras, de que las bocas aquilatan el valor de los relatos y de que desconfía de que los demás crean lo que ella llegó a ver con sus propios ojos (Sanz, 2006: 9-11).

En esta secuencia inaugural de la novela, Clara, la cuidadora y asistenta de casa de los Amaro, se topa con la erótica escena de los particulares cuidados de Susana Renán para con el anciano Felipe Amaro. La asistenta no da crédito a lo que ve. No sabe si es real la visión o son caprichos de su imaginación, pero ante las dudas y sospechas que genera la escena presenciada la asistenta prefiere callar, no reaccionar y, en todo caso, reservar la revelación del impactante acto observado para el momento más oportuno, «prefiere dosificar la información y observar la reacción de los distintos miembros de la familia».

Con este plano como telón de fondo, la novela se aleja de una trama argumental clásica y su ceñida urdimbre evolucionará mediante la presentación, caracterización e individualización de los ocho protagonistas narrativos de la misma y a través de la indagación en las redes personales que los unen, distancian, relacionan y oprimen. En la novela, se ofrece el retrato de la clase media-alta española a través de la relación de las vidas de la estirpe de los Amaro. Apenas si hay acción alguna, concentrándose la trama de la obra en varios episodios anecdóticos y algunos lances de su historia vital todo ello subordinado y dependiente de la introspección psicológica. Lo más destacado en este sentido es la relación de Felipe Amaro hijo y Susana Renán - historia que ocupa el lugar central de la obra- quienes después de conocerse y de proyectar, él como arquitecto y ella como geriatra, un centro geriátrico, se enamoran, se casan y, finalmente, cuando la vida de Felipe comience a ser rescatada de la vulgaridad e incomprensión que padece gracias a Susana, su hijo, en un lance cargado de odio, de venganza y de aversión se encargue de destrozarle la vida para siempre al desvelarle uno de los escabrosos misterios que envuelven el angelical ser de Susana Renán y provocar con ello la huida de la doctora:

- Y, ahora, papito, te voy a contar por qué mi Pola no va a ir a esa clínica y por qué tú no eres más que un necio.

A partir de ese instante, Felipe Amaro sólo recuerda los labios de Maximiliano, a cámara lenta. Felipe, concentrado en el movimiento de los labios, no puede descifrar las palabras entre la gangosidad de los sonidos, su excesiva 
lentitud, y frunce el ceño, concentrado en la boca de su hijo que le está contando una historia de una pobre asistenta que, entre las paredes de una casa que irradia la música de las Walkirias y se come a sus habitantes, encuentra un cuarto, iluminado por un golpe de luz, en el que una mujer joven, con aspecto de vikinga, cabalga a horcajadas sobre las costillas lampiñas de un viejo que mira hacia la luz en pleno éxtasis berniniano (Sanz, 2006: 268-269).

El resto de la narración partirá de la espiral de esta relación para ir ofreciendo lo que las vidas, sentimientos y pensamientos del resto del clan familiar en sus relaciones con Felipe y en los vínculos entre ellos.

Marta Sanz esboza un nuevo objeto artístico dentro de la cadena de eslabones anudados en torno a la historia de Susana y los viejos, aprovechando una máxima de la autora «si los límites están cambiando, también deben de cambiar los tabúes»y, conforme a ello, reelabora la historia bíblica y la tradición heredada.

Susana no se ofrece como la mujer fiel, sumisa, pasiva y recatada que ante la lascividad de los viejos prefiere morir a ver mancillado su nombre. El personaje de Sanz es una mujer activa, generosa y diligente frente al estatismo, pasividad y resignación de su fuente de inspiración. No tiene reparos en hacer felices a los demás a cualquier precio: «[...] Susana consentidora, que prefiere mirar que ser mirada, tocar que ser tocada, provocar el gozo más que gozar» (Sanz, 2006: 159).

La Susana de Sanz es la reencarnación de la ternura, del amor, del erotismo, de la sensibilidad. Su figura será sublimada por todos, excepto por Clara, quien, a pesar de saber que es especial, no puede ceder a su impulso primario de destrozar anímicamente a Felipe y, con ello, saberse vencedora frente al señor. Después de la llegada de Susana a la familia nada es igual, todo cambia en Felipe. El tiempo se anula. Susana, además de la sensibilidad que muestra hacia los ancianos, es capaz de reparar en lo más insignificante, de descubrir lo imperceptible. Es por tanto un ser más espiritual e irreal que material.

Susana es tan desbordante cual misteriosa, tan hermosa como bondadosa. Al igual que Felipe, aunque de éste no se perciba, se esfuerza en ayudar a los demás. Es una doctora especial que estimula a los demás para recobrar placeres prohibidos u olvidados. Sabe escuchar, sabe actuar, sabe atender y sabe decir la palabra justa que atenúa los sentimientos de culpabilidad de los familiares de los ancianos asilados en el geriátrico. En su repaso por las distintas imágenes pictóricas del cuadro de Susana y los viejos a lo largo del 
tiempo, Felipe da rienda suelta a su imaginación fabulando sobre los sentimientos, verdaderas emociones y velados pensamientos que se pueden esconder bajo las escenas y protagonistas de estas obras:

Hoy mismo, semioculto en un sillón de cuero auténtico que lo abraza hasta tragárselo, Felipe se recrea en las distintas representaciones de Susana y los viejos que la espían: algunas escenas se desarrollan en extraños exteriores con lagos que parecen bañeras artificiales; algunas son escenas nocturnas y otras diurnas, casi todas parecen atardeceres; en ciertos cuadros, Susana aparece turbada, en otros avergonzada, ausente, pícara. Pacatamente seductora o abiertamente incitante, como si fingiera alguna distracción. Los viejos casi siempre son viejos rijosos y risueños. Algunos apuntan con el dedo en dirección a Susana y otros esconden sus extremidades, se sujetan los unos a los otros, briagos de no sé sabe qué elixires. Uno de los viejos esconde la mano, bajo el manto, a la altura del bulto de un sexo que debería haber muerto hace ya muchísimos años; sin embargo, el bulto en la tela, su turgencia y su brillo, llevan a imaginar al atento observador que Susana ha revivido a los muertos y que la verga de ese viejo es un Lázaro resucitado de los brazos de la parca. Susana, en algunos cuadros, lleva el pelo recogido y en otros, suelto sobre los hombros. A veces enseña la nuca y las nalgas; a veces las redondeadas formas del vientre y los pechos pequeños, los pliegues luminosos de la piel. Susana a veces es morena y a veces rubia, a veces su pelo es ceniza, pero su piel siempre pálida, sonrosada, láctea en aquellos puntos en los que la luz del cuadro la enfoca directamente. Casi ninguna de las obras que Felipe va revisando, complacido, expresa vergüenza, sino más bien una sensualidad visual explosiva, por la blandura de las formas, los brillos de las pupilas, los colores de las túnicas orientales de los viejos. Felipe se pregunta si esa sensualidad tendrá que ver con el lugar de nacimiento y con la época de los pintores o si estará ya presente en el episodio bíblico y se promete a sí mismo que mañana comprará un Antiguo Testamento para leer el correspondiente pasaje. Si él fuera creyente, debería darle gracias a Dios por haberse decidido a visitar a su padre, porque allí tuvo la oportunidad de conocer a Susana. O quizá Susana era un regalo de Dios, un premio para Felipe, que había realizado tantas buenas obras. Desde ese día no hace otra cosa más que trabajar, revisar sus catálogos de pintura o reunirse con ella (Sanz, 2006: 132-133).

De la compleja personalidad, bondades y magia espiritual que desprende Susana da cuenta un fragmento en el que Felipe imagina un posible embarazo de la musa:

Susana está rara, pero su marido no se preocupa, porque precisamente esa rareza y ese no saber bien lo que pasa es lo que le mantienen loco, loquito 
por ella. Felipe piensa que, a lo mejor, está embarazada, aunque existen muchos motivos para creer que eso es imposible, porque si, a día de hoy, a Felipe le dijeran que su esposa es virgen, él no encontraría razones de peso para negar el estado angelical del pubis de su esposa. Aunque, quizá, Susana hechicera, Susana Morgana, Susana sanadora, Susana Calipso y Circe, Susana sirena con las cuerdas vocales operadas como los perros de las urbanizaciones elegantes, Susana Urganda, la desconocida, por las noches, se pone en la boca una esencia sedante y, al besar a Felipe, lo induce a un sueño profundo y campestre, en el que él, sumergido, experimenta placeres sin que le queden recuerdos. Felipe se duerme sobre el tapiz de una égloga. Quizás en uno de esos sueños, de los que Felipe no guarda en la memoria, Susana se haya fecundado en soledad, como algunas especies pelágicas, extrayendo de la columna vertebral de Felipe el preciado líquido que perpetúa la vida (Sanz, 2006: 256-257).

Al descubrirse la perversión o secretos de Susana hacia Felipe padres así como los particulares cuidados que regala a los asilados en su clínica, la espiritualidad de Susana se transforma, apareciendo ante la mente de Felipe hijo como una lasciva devoradora de hombres en un cuadro tan grotesco cuan escatológico y «feista», donde Susana, cual personaje lujurioso, es protagonista de un esperpéntico aquelarre sexual:

Se van sucediendo los colores y las formas, y la casta Susana de la pintora Artemisa pierde su pudor rebelde, esa fuerza repelente con la que se aparta de los viejos, y repta hacia los bordes de sus túnicas para babearles los tobillos e ir subiendo, como Linda Lovelace, buscando con qué saciar su garganta profunda; a la Susana de Goya, enrevesada en sí misma, rollo de carne reflexivo, el clítoris le cuelga hasta la mitad del muslo y una Susana, con los ojos en blanco, se deleita en la contemplación de los ejércitos de viejos que la amenazan con sus vergas en alto y sus manos abiertas, que exhiben extendidos sus diez dedos y sus diez uñas. Todos los viejos se abalanzan sobre Susana y la carne ebúrnea de la hembra se colorea de morado. Los viejos violan a Susana por todos los agujeros y, en el batiburrillo de las fisonomías amorfas, Felipe se reconoce, eyaculando sobre el pecho de una mujer, rodeada de heces, con el cabello chorreante a causa de la lluvia provecta y dorada de los viejos miadores de doncellas con el himen remendado. Preusas, Elicias, mujeres de Lázaros de Tormes, concubinas de arciprestes, Maritornes que le chupa la polla a los arrieros de Galicia, entre la paja del pajar. Felipe debía haber tenido presente que, cuando la vida imita al arte, se vuelve asquerosa y, sin embargo, no le desagrada del todo este aquelarre de Susanas masturbadoras y penetradas, lamidas y mordidas, por los ejércitos de viejos que reviven y jadean entre la sangre de su puta (Sanz, 2006: 276-277). 
Y aunque a Felipe no le importa la actitud de Susana ni la verdad o mentira que pueda haber en la revelación de su hijo, nunca recuperará a Susana. Él vive por Susana y su vida tiene sentido por ella. No tiene nada que reprochar ni perdonar porque la ama y para Felipe eso lo es todo, pero Susana escapa: «La desaparición quiere decir que Susana es culpable, pero a Felipe, que se acaba de meter las manos en los bolsillos, ésa es una cuestión que, sin saber muy bien por qué, le da absolutamente igual» (Sanz, 2006: 277).

Las últimas páginas del libro, a través de los pensamientos del nonagenario Felipe, vuelven a provocar un guiño entre la escena clásica y la realidad de ahora con esa Susana complaciente, delicada y compasiva que se entrega a todos y que con su cuerpo trata de rescatar sensaciones y sacudidas olvidadas por los viejos:

Esta muchacha, Susana, debe estar loca. Eso pensé la primera vez que me besó y con su lengua indagaba hasta descubrir mi lengua turbia. Luego, otra veces, cometí la imprudencia de creer que me amaba sólo a mí y, más tarde, volví a pensar esta muchacha debe de estar loca, cuando me reí de mi soberbia y me di cuenta de que yo no era el único de sus amantes. Habría otros más activos. Un hombre, un poco más joven que yo, con pijama y pantuflas que la aguardaba a la puerta de la clínica. Un hombre que podía andar y esconderse con ella, detrás de los setos del jardín. Y también debía de haber hombres viejos, pero independientes, tanto que aún se echaban colonia para recibirla y le hacian regalos y se sentían amados en exclusiva, engañándose, o tal vez, sin engañarse en lo del amor, aunque sí en lo de la exclusividad, prohibiéndose sentirse halagados, porque no entienden que Susana es un dádiva inmerecida y se convencen a sí mismos de que es una recompensa a sus bondades, a la persistencia del olor a hombre joven que aún les queda en el cuerpo, a su atractivo inmanente, aprisionado en su voluntad de vivir con plenitud. Hombres, pagados de sí mismos, que incluso, encelados, le darían a Susana una bofetada o le harían algún desplante. A mí me gustaría escuchar qué es lo que se estarán contando los viejos mientras espían a Susana (Sanz, 2006: 300-301).

La novela concluye con un nuevo guiño de la escritora hacia la fuente desde la que se traza la obra cuando aduce que le gustaría saber qué se cuentan los viejos dejando así abiertas las puertas a otras interpretaciones y otras fabulaciones sobre la imagen de la protagonista femenina Susana o sobre los pensamientos de sus antagonistas masculinos los viejos.

Según ella misma declaró, con Susana y los viejos Marta Sanz pretendía batir conciencias y, a la vez, desvelar «la hipocresía de un sector de la so- 
ciedad española anclada en valores procedentes de una moral católica que para evitar el dolor de la muerte inocula el miedo a la vida creando mitos y tabúes que producen una profunda infelicidad. En Susana y los viejos se abordan temas incómodos como la enfermedad y la vejez desde una perspectiva materialista en la que el sexo es una forma de calor para combatir la soledad y el frío de la muerte» (Díaz, 2008).

Con esta obra se quiere intervenir en la realidad. La autora es consciente de que se abordan temas escabrosos e incómodos como la soledad, la alienación de los seres humanos de hoy, el fracaso familiar, la inadaptación social, la sexualidad y carnalidad, el tema del cuerpo, amores y desamores, pasiones y odios, el pesimismo y negatividad, las múltiples confrontaciones generacionales, sexuales o de clase, los problemas de identidad y los juegos especulares sobre el individuo y un «yo» que no se reconoce... Todo ellos atraviesan las comisuras narrativas de esta novela ovillando la panorámica de la existencia de los personajes de Sanz.

Pero no hay que olvidar en esta obra los puentes que se tienden con el mundo del cine, del arte y de la música intertextualidades que enriquecen la narración y muestran el gusto culto de su autora. De la misma manera habría que atender a todos aquellos aspectos relacionados con el tratamiento de la vejez, de la enfermedad y de la muerte porque ocupa un lugar importante. Ni conviene relegar a un segundo plano las consideraciones feministas que se plasman en la novela, que pueden ser abordadas desde el punto de vista de los postulados feministas defendidos o declarados, al tratamiento dispensado por la autora sobre sus personajes femeninos especialmente sobre Clara, Lorena y Susana.

La novela es rica en imágenes, técnicas narrativas y recursos expresivos. Técnicas expresionistas que se ceban sobre lo más sórdido, lo más macabro, lo trágico o lo «feísta» conectan con cuadros surrealistas y planos superpuestos propios del lenguaje cinematográfico. Sería interesante detenerse en la superposición de las escenas y en la manera de narrar, ya que en lugar de la relación directa de conversaciones, acciones y expresión de sentimientos o de pensamientos de los personajes, el narrador sugiere, insinúa, se dicen las cosas de manera implícita, valiéndose para ello de estructuras indirectas, de rodeos o elipsis que, sin embargo, aportan al lector la información necesaria.

El lenguaje directo, agresivo, mordaz e incluso en ocasiones malsonante, el ritmo trepidante, dinámico y versátil dominado por períodos oracionales breves que profieren al relato la misma rapidez y estrés con las que se tiene que convivir cada día, las estructuras enumerativas, el detallismo junto con la 
exageración, etc., son algunas otras de las cuestiones que llaman la atención de esta obra y que invitan a un estudio detallado sobre la misma.

Pero, para concluir, basten las anotaciones apuntadas para mostrar algunas de las pinceladas de una obra que subvierte la tradición que reelabora una historia clásica y que ofrece una lectura renovadora de un pasaje amoldándolo a nuestro tiempo y, como se puede comprobar, con la intención provocadora de azuzar conciencias y de hostigar lo acomodaticio y los valores de nuestra sociedad para que emerjan esas otras realidades innombradas que nos rodean.

\section{REFERENCIAS BIBLIOGRÁFICAS}

BECERRA MAYOR, D. (2008). «Sometimiento y reproducción ideológica. Lectura de Lección de anatomía, de Marta Sanz»: http://www.rebelion.org/noticia.php?id=68398 (consultado el 10/02/2011).

BÉRTOLO, C. (1996). «Novela y público». En Posmodernité et écriture narrative dans l Espagne contemporaine, Georges Tyras (ed.), 33-48. Grenoble: CERHIUS.

CASTRO GARCÍA, M. ${ }^{a}$ I. (2002). «La novela contemporánea de mujer (1975-2000). De la ficción autobiográfica, la autobiografía y la novelacrónica». En Las mujeres escritoras en la historia de la literatura española, Lucía Montejo Gurruchaga y Nieves Baranda Leturio (coords.), 167-188. Madrid: UNED.

CIPLIJAUSKAITÉ, B. (1994). La novela femenina contemporánea (19701985). Hacia una tipología de la narración en primera persona. Barcelona: Anthropos.

DÍAZ, E. (2008). «Entrevista con la escritora española Marta Sanz. La literatura no es inofensiva». La Jiribilla. Revista de Cultura Cubana 355, 23 29 febrero: $h t t p: / / w w w . l a j i r i b i l l a . c o . c u / 2008 / n 355 \_02 / 355 \_44 . h t m l$ (consultado el 10/02/2011).

GALLEGO, D. (2006). «Marta Sanz. Escritora finalista del Premio Nadal». Diario Sur, 16 de febrero: http://www.diariosur.es/pg060216/ prensa/noticias/Cultura/200602/16/SUR-CUL-273.html (consultado el 10/02/2011).

JIMÉNEZ, J. (1994). La vida como azar. Complejidad de lo moderno. Barcelona: Destino. 
LÓPEZ CABRALES, M. a del M. (2000). Palabras de mujer. Madrid: Narcea. LYON, D. (1994). Postmodernidad. Madrid: Alianza Editorial.

PEDREGAL CASANOVA, R. (2008). «Reseña del libro La lección de anatomía de Marta Sanz. Por qué llegó a importarnos el mundo»: http://www.rebelion.org/noticia.php? id $=74474$ (consultado el 12/03/2010).

GARCÍA, L. (2006). «Entrevista a Marta Sanz»: http://www.literaturas.com/ v010/sec0605/entrevistas/entrevistas-03.htm (consultado el 15/12/2008).

JAMESON, F. (1991). El posmodernismo o la lógica cultural del capitalismo avanzado. Barcelona: Paidós.

MARTÍN, S. (1997). «Narrativa española tercer milenio (guía para usuarios)». En Páginas Amarillas, IX-XXX. Madrid: Lengua de Trapo.

MATUTE, I. (2006). «Susana y los viejos, Marta Sanz». Luke 78, octubre: http://www.espacioluke.com/2006/Octubre2006/ineslite.html (consultado el 10/02/2011).

NAVAJAS, G. (1987). Teoría y práctica de la novela española posmoderna. Barcelona: Mall.

RUZ VELASCO, D. (1999). «La soledad era esto y la postmodernidad. El sujeto escriptivo, el sueño mimético y la antípoda». Espéculo. Revista de Estudios Literarios 11: http://www.ucm.es/info/especulo/numerol1/ millas.html (consultado el 10/02/2011).

SANTOS-FEBRES, M. (2007). «Micro-entrevista Marta Sanz»: http://mayrasantosfebres.blogspot.com/2007/06/micro-entrevista-marta-sanz.html (consultado el 15/12/2008).

SANZ, M. (2003a). «Entrevista a Marta Sanz. Marta Sanz, en 5 minutos»: http://www.elmundo.es/elmundolibro/especiales/2003/03/la_novela_que_ vienele_marta.html (consultado el 15/12/2008).

- (2003b). «Marta Sanz publica su última novela, Animales domésticos»: http://www.elmundo.es/elmundolibro/2003/01/26/anticuario/1043435685.html (consultado el 15/12/2008).

- (2006). Susana y los viejos. Madrid: Destino.

- (2007). «Ver, oír y no callar». Público, 24 de octubre: http://blogs.publico.es/dominiopublico/73/ver-oir-y-no-callar/ (consultado el 10/12/2010). 
- (2008). «La escritora Marta Sanz desvela su intimidad en Lección de anatomía: http://www.soitu.es/soitu/2008/05/11/info/1210520573_ 865149.html (consultado el 10/12/2010).

SANZ VILLANUEVA, S. (2006). «Susana y viejos»: http://www.elcultural.es/version_papel/LETRAS/16567/Susana_y_los_viejos (consultado el 15/12/2008).

SILVA, L. (et alii) (2007). Leyendas de Bécquer. Madrid: 451 Editores.

Recibido el 15 de diciembre de 2010.

Aceptado el 16 de septiembre de 2011. 
